\title{
Pharmacoeconomic Evaluation of Novel Oral Anticoagulants in Patients with Cardiovascular Diseases: A Systematic Review
}

\author{
Ahmed Ibrahim Nouri ${ }^{1}$, Maha Aldraimly ${ }^{2}$ and Mohamed Azmi Hassali ${ }^{3}$ \\ ${ }^{1}$ Washington University for Health and Science, Palestine \\ ${ }^{2}$ King Abdulaziz Medical City, Saudi Arabia \\ ${ }^{3}$ Universiti Sains Malaysia, Malaysia
}

*Corresponding author: Ahmed Ibrahim Nouri, Washington University for Health and Science, Palestine. Email: ahmad090@hotmail.com

Received Date: January 12, 2021

Published Date: February 04, 2021

\section{Abstract}

Background: Several economic evaluations have been performed in various countries to demonstrate the efficacy of novel oral anticoagulants versus warfarin in patients with cardiovascular diseases. This systematic review aims to provide a comprehensive summarization of the pharmacoeconomic performance of four novel oral anticoagulants, rivaroxaban, apixaban, edoxaban and dabigatran usage in patients with cardiovascular diseases.

Methods: Relevant databases including Embase, Cochrane Library, Medline, CINAHL and Science Direct were used to search for qualitative and quantitative studies. The reviewers independently extracted data according to PRISMA checklist.

Results: There were 43 studies found according to the inclusion criteria. We identified six types of intervention including cost-effectiveness comparison between the novel oral anticoagulants, cost-effectiveness comparison between the novel oral anticoagulants and warfarin, apixaban to warfarin, dabigatran to warfarin, rivaroxaban to warfarin, and edoxaban to warfarin. Outcomes of the interventions included Quality-adjusted Life Year (QALY) , Incremental Cost-effectiveness Ratio (ICER), Incremental Cost-utility Ratio (ICUR), Life Year Gained (LYG), mean-life years, life expectancy, the rate of recurrence, Confidence Interval (CI), willingness-to-pay, number of strokes prevented and types of costs.

Conclusion: Numerous studies investigated novel oral anticoagulants since they were introduced to clinical practice, especially for their various roles in management of cardiovascular diseases. With proven NOAC clinical superiority and the lower need of follow-up visits and lab tests, NOAC economic profile is a broad area of research. The current study managed to review 43 studies investigating NOACs. Despite the variations in quality, sampling, design of studies investigating NOACs, all studies reported that NOAC are more cost-effective than warfarin in terms of indirect costs and quality-adjusted life year.

Keywords: Pharmacoeconomic; Cost-effectiveness; Novel oral anticoagulants; Dabigatran; rivaroxaban; Apixaban; Edoxaban; Cardiovascular diseases

\section{Introduction}

For decades, the oral anticoagulant warfarin remained the gold standard of medical management for many cardiovascular diseases and main pharmacological agents for the prophylaxis of venous thromboembolism [1]. Among these cardiovascular patients, the vitamin $\mathrm{K}$ antagonists are especially beneficial to patients with venous thromboembolism and for the prevention of stroke. In

terms of clinical consideration, warfarin displays several limitations and disadvantages. The narrow therapeutic window and vast drugdrug and drug-food interactions properties of warfarin render it clinically difficult to use [2]. Precise dose adjustment and frequent dose monitoring are of utmost importance because inappropriate dose can lead to many adverse clinical events. Warfarin over-dose 
will increase the risk of serious bleeding while under-dose will not produce the therapeutic outcomes desired, for example stroke prevention [3].

Novel oral anticoagulants (NOACs) are becoming more important in clinical uses due to the limitations of warfarin mentioned above. NOACs can be divided into direct factor Xa inhibitors (rivaroxaban, apixaban and edoxaban) and direct thrombin inhibitors (dabigatran). In terms of bleeding risk, NOACs display a significantly lower risk of intracranial and intracerebral bleeding than warfarin [4]. NOACs display evidence that they are at least as effective as warfarin if not superior to warfarin in the clinical treatment of patients with systemic embolism and as a prophylaxis for stroke in atrial fibrillation patients [5-6].

Even though NOACs show a superior performance in clinical uses compared to warfarin, but the main drawback on prescribing NOACs to patients instead of warfarin is due to the high daily costs. The rising clinical importance of NOACs, as well as their higher cost, impose a question on the pharmacoeconomic performance of the NOACs. There are numerous studies done in many countries to evaluate the pharmacoeconomic profile of the NOACs.

The aim of this systematic review is to evaluate the pharmacoeconomic performance of four novel oral anticoagulants, rivaroxaban, apixaban, edoxaban and dabigatran usage in patients with cardiovascular diseases (deep vein thrombosis, pulmonary embolism, atrial fibrillation and stroke).

\section{Methodology}

A search was conducted in Google Scholar, Embase, Cochrane Library, Medline, CINAHL and Science Direct using search algorithms to identify relevant pharmacoeconomic publications of novel oral anticoagulants in patients with cardiovascular diseases. Processes throughout systematic review were carried out using Preferred Reporting Items for Systematic Reviews and MetaAnalysis (PRISMA) statement. The search identified publications with the keywords pharmacoeconomic, cost-effectiveness, novel oral anticoagulants, dabigatran, rivaroxaban, apixaban, edoxaban, cardiovascular diseases, stroke, atrial fibrillation, deep vein thrombosis or pulmonary embolism. Both cost studies and economic evaluation of novel oral anticoagulants were considered.

While cost studies estimate expenses associated with a particular treatment for cardiovascular diseases, economic evaluations assess both health costs and benefits associated with a drug against its comparator(s). Economic evaluations usually include cost-effectiveness analyses, cost-utility analyses, and cost-benefit analyses depending on how health benefits [natural units, quality-adjusted-life-years (QALYs)] and monetary terms are measured. QALYs incorporated both morbidity (as the quality of life) and mortality. Cost-effectiveness analyses looks at a single quantified effectiveness measure of the cost per unit. There are many variations in cost-effectiveness analyses that can be considered; cost consequence and cost-minimization analyses, with comparing cost outcomes due to health benefits. Economic evaluation in health care consider the resources consumed by patients, productivity losses, health sector and other sectors as well. A treatment is usually considered cost-effective if the incremental cost-effectiveness ratio (ICER) is below the commonly used threshold for the given country. Various threshold are available such as $\$ 50,000$ per QALY in the United States and \$20,000-\$100,000 per QALY in Canada.

The title and/or abstract of articles published between 2008 and 2018 pertaining to novel oral anticoagulants were searched for the keywords. "Grey" literature (ie, material that can be referenced, but is not published in peer-reviewed, indexed medical journals) was not examined and not included in this review. From the review questions, the author concluded that the question is a therapy question. Hence, the best evidence would be a randomized controlled trial, cohort study, and case-control. Abstracts were included when all of the following were true: cost-effectiveness of different novel oral anticoagulants on patients with cardiovascular diseases and published from 2008 to 2018. Articles published in English language only were accepted; those that did not meet the pre-stated criteria were excluded. Different types of novel oral anticoagulants (dabigatran, rivaroxaban, apixaban and edoxaban) used in patients with cardiovascular diseases were included in this review. Articles that have not mentioned novel oral anticoagulants were excluded. Patients with cardiovascular diseases (stroke, deep vein thrombosis, pulmonary embolism and atrial fibrillation); any gender; any age and any severity of cardiovascular diseases were included in this review. Populations were not restricted to one country or place. All papers around the world will be examined and reviewed.

For data extraction, data extracted from included studies using data extraction from guided by standardized extraction data tool by Cochrane Collaboration. The extracted data assured to match with the review question and fulfill the review objectives. A table was used to present details of the characteristic of included studies, such as author, country, year of study; interventions, sample and study design. Data on study design, inputs, results and authors' conclusions were extracted.

\section{Results}

\section{Study Selection}

At the beginning, 120 publications were retrieved from EMBASE, Google Scholar, Pubmed, Cochrane, CINAHL and Science Direct. From going through the references of the 120 publications, an additional six publications were identified owing up to the total of 126 publications chosen for further screening. The numbers were narrowed down to 95 after removing the duplicates. After the literature was screened for eligibility, 43 articles were included in 
the qualitative synthesis and 52 publications were excluded due to the reasons stated in Figure 1. A vast majority of the articles were removed due to the fact that they were only systematic reviews. Other reasons for exclusion included reasons such as the articles not being associated with pharmacoeconomics or cost-effectiveness, the irrelevance of the literature to the Novel Anti Coagulants of interest, the publications were in the form of meta-analysis as well as the articles retrieved were not available in English.

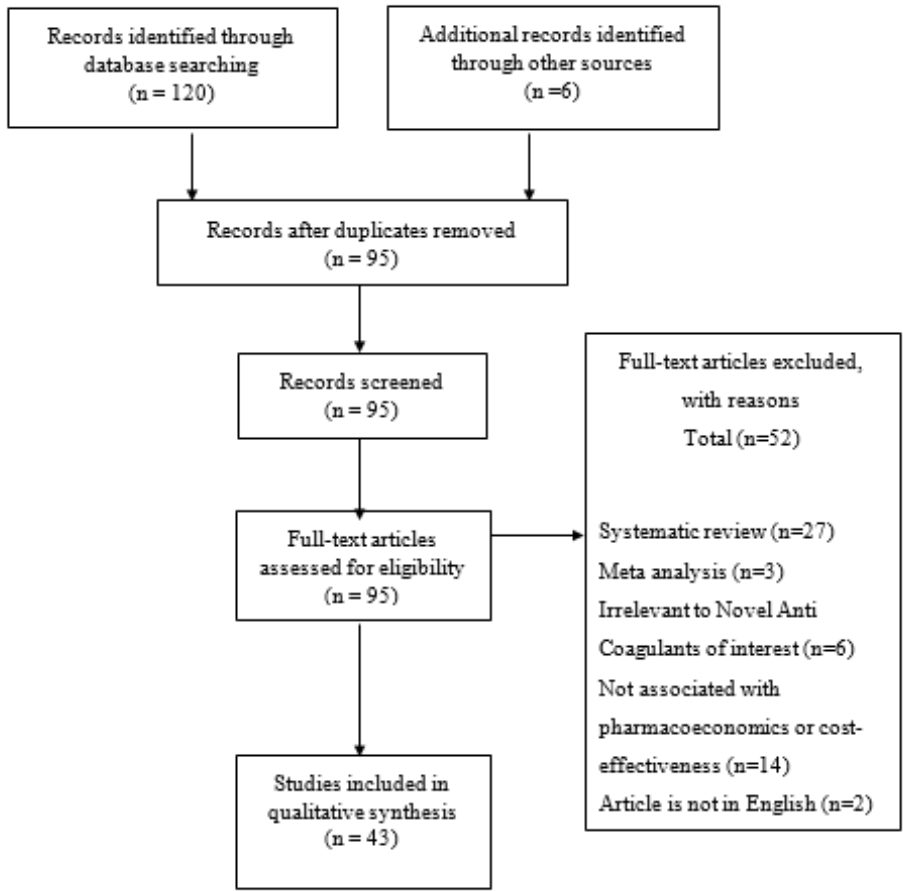

Figure 1: Flow diagram of publications included and excluded in the review.

\section{Characteristics of Studies}

Among the studies, the sample size was in the range of 100 to 50,000 patients from all over the world. This review included randomized controlled trials, cohort and case-control studies from the year of 2010 to 2017 . Three studies were conducted in Germany, nine in the United Kingdom, one in Japan, Slovenia, Australia, Singapore, Sweden, California, Hong Kong, Ireland, France, Portuguese respectively, two in Sweden, four in the Netherlands, seven in the United States of America, two in Canada, two in England and five were unclear. 25 studies were using Markov model, five studies were using Randomized Control Trials (RCT) together with a cohort study, six using cohort study only and Randomized Control Trials (RCT) only besides one using retrospective observational study.

Across studies, the reported outcome of interest differed considerably. Reported objective measures of cost-effectiveness included Quality-adjusted Life Year (QALY), Incremental Costeffectiveness Ratio (ICER), Incremental Cost-utility Ratio (ICUR), Life Year Gained (LYG), mean-life years, life expectancy, rate of recurrence, Confidence Interval $(\mathrm{CI})$, willingness-to-pay, number of strokes prevented and types of costs such as direct medical cost, long-term care cost, costs accumulated, total medical costs, medical cost avoidance and clinical event costs avoided.

\section{Cost-effectiveness comparison among the novel oral anticoagulants (apixaban, dabigatran, edoxaban, rivaroxaban)}

This review identified 7 primary studies examining the comparison of the cost-effectiveness of new oral anticoagulants. Most studies were retrospective analyses reporting qualityadjusted life years (QALY), total costs, and incremental costeffectiveness ratios (ICER). 4 of the studies were conducted in the United Kingdom with 1 from the Netherlands and the last two were unknown setting.

In the UK (2015), patients received dabigatran (7.68 QALYs) has higher QALYs compare to apixaban (7.63 QALYs) and rivaroxaban (7.47 QALYs). For the lifetime cost, dabigatran also is the cheapest when compared to other novel oral anticoagulants. The total lifetime costs are dabigatran $((£ 23,342)$, apixaban $(£ 24,014)$ and rivaroxaban $(£ 25,220)[7]$. 
In 2014 , ICER is $£ 9611, £ 4497$ and $£ 5305$ per QALY gained with apixaban compared with dabigatran $150 \mathrm{mg}$ BID, dabigatran $110 \mathrm{mg}$ BID, and rivaroxaban $20 \mathrm{mg}$ once daily, respectively [8]. In terms of therapeutic management costs, compared with dabigatran $110 \mathrm{mg}$, dabigatran $150 \mathrm{mg}$, and rivaroxaban, respectively, apixaban yielded additional anticoagulant (drug) and management costs. The average cost-offsets in monitoring and clinical event-related costs (lifetime reduction) are $£ 249, £ 140$, and $£ 269$ [9].

The estimated incremental cost-effectiveness ratio was $£ 9611$, $£ 4497$, and $£ 5305$ per quality-adjusted life year gained with apixaban compared with dabigatran 150 mg BID, dabigatran 110 mg BID, and rivaroxaban $20 \mathrm{mg}$ once daily, respectively [10]. Besides that, the annual total medical cost avoidances (2014) is dabigatran $(\$ 2,794)$, rivaroxaban $(\$ 2,948)$, apixaban $2.5 \mathrm{mg}(\$ 4,249)$ and apixaban $5 \mathrm{mg}(\$ 4,244)[11]$.

In the Netherlands (2014), QALYs were increased by rivaroxaban in 0.166 , apixaban in 0.365 and dabigatran in 0.374 . When ICER compared with the coumarin derivative, rivaroxaban showed - €34,248 per QALY gained, apixaban showed €13,024 per QALY gained and dabigatran showed $€ 14,626$ per QALY gained A willingness-to-pay threshold of $€ 20,000$ or $€ 36,000$ per QALY gained of apixaban is (37 and $42 \%$, respectively), dabigatran (41 and $48 \%$, respectively) and rivaroxaban (5 and $4 \%$, respectively) [12]. In conclusion, dabigatran yields more total QALYs at lower lifetime costs than apixaban and rivaroxaban.

\section{Cost-effectiveness comparison among the novel oral anticoagulants to warfarin}

Eight primary studies had identified as the comparison of the cost-effectiveness of new oral anticoagulants to warfarin or aspirin. Most studies were retrospective analyses reporting quality-adjusted life years (QALY), total costs, and incremental cost-effectiveness ratios (ICER) and willingness to Pay. 2 of the studies were conducted in United States 2 of them conducted in Canada with every 1 study from the German, Slovenia, Singapore and France respectively.

In the United State (2013), the total cost of warfarin is $(\$ 77$ 813), rivaroxaban $20 \mathrm{mg}$ (\$78 738 \pm \$1852), dabigatran $150 \mathrm{mg}$

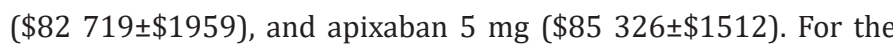
QALY, apixaban $5 \mathrm{mg}$ is 8.47 , dabigatran $150 \mathrm{mg}$ is $(8.41 \pm 0.07)$, rivaroxaban $20 \mathrm{mg}$ is $(8.26 \pm 0.06)$, and warfarin is $(7.97 \pm 0.04)$. Cost-effectiveness of apixaban $5 \mathrm{mg}$ is $45.1 \%$, dabigatran $150 \mathrm{mg}$ is $40 \%$, whereby rivaroxaban $20 \mathrm{mg}$ is $14.9 \%$, and warfarin is $0 \%$. The ICER is \$15 026 per QALY gained [13]. Another study gave results that QALY is 9.38 for apixaban and 9.02 for warfarin. Total cost of warfarin was $\$ 46241$ and $\$ 58889$ for rivaroxaban. In 2016, for ICER, apixaban showed \$25816/QALY [14]. In the Canada (2013), one study showed QALYs for dabigatran is 6.543, rivaroxaban is 6.541 and 6.617 for dabigatran and apixaban. The total costs take $\$ 22804$ for (dabigatran), \$22016 for rivaroxaban, \$21966 for apixaban, whereby $\$ 21486$ for dabigatran and $\$ 18620$ for warfarin. Another study provided an additional 0.506 life-years and 0.638 QALYs relative to warfarin [15]. A study from the German (2014) 7.56-7.64 QALYs was gained for warfarin whereby NOACs added additional 0.04-0.19 QALYs. The total cost of warfarin ranged from $£ 7622$ to 9069 and NOACs ranged from $£ 19537$ to 20048 [16].

In the Slovenia (2014), QALY for standard warfarin treatment with a mean TTR of $60.0 \%$ is 7.218 QALYs. The highest average survival was estimated with apixaban, followed by dabigatran and edoxaban. These three medicines performed better than warfarin for more than 0.2 QALY (Janzic and Kos, 2015). In the Singapore (2014), QALYs for anticoagulants drug are warfarin (8.75), dabigatran $110 \mathrm{mg}$ (8.73), dabigatran $150 \mathrm{mg}$ (8.82), and rivaroxaban (9.33). The total costs of warfarin (SG\$ 34,648), dabigatran 110mg (SG\$54,919), dabigatran150mg (SG\$50,484), and rivaroxaban (SG\$51,975). The ICER of rivaroxaban versus warfarin is SG\$29,697, approximate US\$26,727 per QALY [18].

Lastly, in France (2014), the study concluded that warfarin and apixaban were the two optimal treatment choices, as the other five treatment strategies which including aspirin, dabigatran 110 $\mathrm{mg}$, dabigatran in sequential dosages, dabigatran $150 \mathrm{mg}$, and rivaroxaban [19]. In a nutshell, in term of cost, QALYs, novel oral anticoagulants show higher cost-effectiveness than warfarin.

\section{Cost-effectiveness comparison among the apixaban to warfarin}

This review identified eight primary studies examining the comparison of the cost-effectiveness of apixaban to warfarin. These studies were retrospective analyses reporting quality-adjusted life years (QALY), total costs, and incremental cost-effectiveness ratios (ICER). Two of the studies were conducted in the United Kingdom and the United States respectively. One study is from the Japan, One from the Sweden and the one from the Australia. The last study, unfortunately the setting was unknown.

In the United Kingdom (2016), studies showed that apixaban was cost-effective compared with vitamin $\mathrm{K}$ antagonist at an incremental cost-effectiveness ratio of 2520 pounds per QALY gained and was a dominant alternative to either rivaroxaban or LMWH/Dabigatran [20]. On the other hand, in 2014, apixaban was projected to increase life expectancy and quality-adjusted life years (QALYS) compared with warfarin and aspirin. The estimated incremental cost-effectiveness ratio was $£ 11909$ and $£ 7196$ per QALY gained with apixaban compared with warfarin and aspirin, respectively [21].

In United State (2012), QALYS was 10.69 and 11.16 years for warfarin and apixaban respectively. The study showed total costs were $\$ 94,941$ for warfarin and $\$ 86,007$ for apixaban [22] 
In another paper, the researcher concluded that apixaban is more cost-effective, although warfarin is superior if apixaban was $2 \%$ less effective than expected [23].

While in the Japan (2015), it showed that apixaban increases life expectancy by 0.231 year or 0.240 QALYs while treatment cost increased by $¥ 511,692$ compared to warfarin. The incremental costeffectiveness ratio was $¥ 2,135,743$ per QALY. When the willingnessto-pay threshold was set at approximately $\geq ¥ 2,250,000$ per QALY, the probability of apixaban being cost-effective was $\geq 50 \%$ [24]. A study in the Sweden (2014) concluded that in warfarin suitable population, the QALYs was 6,71 for apixaban and 6,51 for warfarin. For warfarin unsuitable population, the QALYs was 6.70 for apixaban and 6.41 for warfarin. In cost-effectiveness, apixaban was predicted to lead to 19 fewer strokes, 43 fewer major bleeds, 23 fewer cardiovascular related death in warfarin suitable population. In warfarin unsuitable population, apixaban was predicted to lead to 70 fewer strokes, 39 fewer major bleeds, 56 fewer CV-related deaths [25].

In Australia (2013), when patient receive warfarin therapy, it showed 7.72 years of life lived (YLL) and 5.84 QALYs at a net cost of AUD\$ 24,641 per person. Apixaban therapy resulted in 8.05 YLL and 6.15 QALYs at a net cost of AUD\$28,949 per person. Apixaban provided a 0.33 LYG and 0.31 per QALYs at an incremental cost of AUD\$ 4,308 [26].

\section{Cost-effectiveness comparison among the dabigatran to warfarin}

This review identified most primary studies on examining the comparison of the cost-effectiveness of dabigatran to warfarin, which is 12 studies. Most studies were retrospective analyses reporting quality-adjusted life years (QALY), total costs, and incremental cost-effectiveness ratios (ICER). Among the 12 studies, 3 of them from the United State and the United Kingdom respectively. 2 of the studies were conducted in Netherland with each one study from Hong Kong, Ireland and Sweden.

In United State (2012), QALYS was 10.28 in warfarin, 10.70 in low dose dabigatran, and highest in high dose dabigatran, 10.84 When the ICER is compared with warfarin, low-dose dabigatran showed \$51 229 per QALY and high dose dabigatran showed \$45 372 per QALY [27]. Another US study (2012) suggested 4.27 QALYs in dabigatran, 3.91 QALYs in warfarin and ICER of \$25 000 in dabigatran [28]. On the other hand, in 2011, dabigatran of 8.54 QALYs and warfarin of 8.40 QALYs are estimated in St. Louis [29].

While in the United Kingdom (2011), QALYs become slightly lower, only 8.06 QALYs in dabigatran) with 7.82 in warfarin and 7.59 in aspirin. ICER concluded $€ 4831 / \mathrm{QALY}$ in dabigatran etexilate and $£ 20000 /$ QALY in warfarin [30]. On the other hand, another study (2012) suggested 0.094 QALYs in dabigatran etexilate and 0.146
QALYs in high dose of dabigatran etexilate with ICERs (€/QALY) of 23082 of dabigatran etexilate [31]. The third UK studies (2011) give 0.094 QALYs in low dose of dabigatran etexilate, 0.146 QALYS in high dose of dabigatran etexilate. ICERs of dabigatran etexilate gives $£ 23,082 /$ QALY [32]

The willingness to pay threshold of Netherland (2016) residents is $€ 20,000$ per QALY. The probability that dabigatran is cost-effective reach 99\%. ICER is €20,000/QALY [33]. Besides that, in another Netherland study suggested 0.0349 QALYs in dabigatran with ICERs (€/QALY) of 20,000 (dabigatran) vs 2158(vitamin K antagonist) vs 33,379(no treatment) [34]. In the Sweden (2012), study reported total cost of warfarin ( $€ 24$ 797), dabigatran $(€ 27,009)$. The number of strokes prevented by taking warfarin is lower in 0.52 and dabigatran $(0.37$. However, for the life years gained, dabigatran (12.11) is higher than warfarin (11.83). QALY of warfarin (8.31) and dabigatran (8.60) was reported. When dabigatran compared with warfarin-, cost per QALY is $€ 7742$ and cost per life year is €7699 [35].

A study from Hong Kong (2013) suggested ICER of US $\$ 68333$ (dabigatran) and US\$20500 (warfarin) [36]. By comparison, Ireland (2012) suggested QALY of 10065 on dabigatran with ICER of USD 13810 [37].

\section{Cost-effectiveness comparison among the rivaroxaban to warfarin}

Six primary studies had identified as the comparison of the cost-effectiveness of rivaroxaban to warfarin. Most outcomes are quality-adjusted life years (QALY), total costs, and incremental cost-effectiveness ratios (ICER). Each of the studies is conducted in different country which are the German, United Kingdom, Netherland, United State, Portuguese and one with unknown setting.

Quality-adjusted life expectancy in patients with non-valvular $\mathrm{AF}$ in the German (2014) is 11.06 QALYs when they receive rivaroxaban. When they treated with adjusted-dose warfarin, the QALYs is 10.35 . The corresponding total costs were $€ 9,464$ for warfarin and $€ 20,238$ in rivaroxaban. ICER for rivaroxaban compared with warfarin is €15,207 per QALY [38].

In UK (2010), the study investigated rate of recurrence as its outcome of interest. Rivaroxaban had non inferior efficacy with respect to the primary outcome (36 events [2.1\%], vs. 51 events with vitamin $\mathrm{K}$ antagonist [3.0\%]. The hazard ratio is $0.68 ; 95 \%$ confidence interval $[\mathrm{CI}]$ ranged from 0.44 to 1.04 . $\mathrm{P}<0.001$ ). Rivaroxaban had superior efficacy (8 events [1.3\%], vs. 42 with placebo [7.1\%]; hazard ratio, 0.18 ; $95 \% \mathrm{CI}, 0.09$ to 0.39 ; $\mathrm{P}<0.001$ ). Four patients in the rivaroxaban group had nonfatal major bleeding (0.7\%), versus none in the placebo group with $\mathrm{P}$ of 0.11 [39]. 
Rivaroxaban is the better treatment option for the prevention of ischemic strokes in premenopausal women in $61 \%$ of the iteration, as reported in the Netherlands (2017) [40]. In United State (2012), total costs are $\$ 94,456$ in rivaroxaban vs $\$ 88,544$ in Warfarin. QALYs was 10.027 in Rivaroxaban versus 9.812 in Warfarin. Apart from that, ICERs (\$/QALY) is 27,498 in Rivaroxaban) when compared to warfarin [9]. Lastly, in Portuguese (2014), the study showed although rivaroxaban gets additional cost of €81, QALYs increase 0.021 and life increase 0.023 with ICER is €3494/LY, €3895/QALY [41].

\section{Cost-effectiveness comparison among the edoxaban to warfarin}

Only 2 primary studies of comparison of cost-effectiveness of edoxaban to warfarin are identified. One of them conducted in the German while the other one is non-available setting. In the German (2015), the ICER for edoxaban 60mg was lower compared to edoxaban $30 \mathrm{mg}$ daily. Compared to the other NOAC regimens, edoxaban $60 \mathrm{mg}$ had the lowest ICER. In the two-way sensitivity analysis, edoxaban had set willingness to pay of 50.000C per QALY against INR-dose-adjusted warfarin. In probabilistic sensitivity analyses, edoxaban $60 \mathrm{mg}$ od and edoxaban $30 \mathrm{mg}$ od set willingness-to-pay at threshold of 52.000C per QALY and 67.000C per QALY [42]. The other studies suggested 8.425 QALYs in warfarin and higher QALYs in edoxaban, which is 9.022 QALYs. The ICUR gained was €7,713/QALY [43].

\section{Discussion}

The objective of this review is to study the economic outcomes of application of Novel Oral Anti-Coagulants (NOAC) in patients with cardiovascular disease. The four currently available NOAC are dabigatran, rivaroxaban, apixaban and edoxaban. There are a total of 43 articles included in this systematic review study which comprise 7 articles that compare the cost-effectiveness among the NOAC, 8 articles on cost-effectiveness of NOAC compared with warfarin, and a total of $8,12,8$ and 2 articles comparing the costeffectiveness of apixaban, dabigatran, rivaroxaban and edoxaban, respectively, with warfarin.

When NOAC is compared with warfarin, the result shows that NOAC is more cost-effective [ $13-15,17-18,23,44]$ despite the cost of warfarin is much cheaper than all the 4 NOAC $[13,15-16,18)$. This can be explained from the QALYs gained for treatment with NOAC are higher than that of warfarin [13-19]. When NOAC is compared among each other, there is a study reported that dabigatran yields more total QALYs at lower lifetime costs than apixaban and rivaroxaban, thus making them conclude that dabigatran is more cost-effective than other NOAC [7]. In overall, apixaban is said to be the most cost-effective out of all NOAC where the usage of apixaban shows a reduction in medical cost $[23,26]$ and the average survival of this drug is the highest $[17,26]$. Although the cost of this drug is quite high $[13,15]$, but the QALYs gains is also relatively high [13$15]$.

Besides that, this review found that studies from different countries show different preferences. In the German, a study done in the year of 2014 concluded that rivaroxaban was found to be more cost-effective than warfarin with an ICER of €15,207 per QALY gained [38], whereas in 2015, a different study reported that edoxaban in addition to apixaban may be regarded as the most costeffective NOAC [42]. There are a lot of studies done in UK starting from 2010 to the latest in 2016 and the result varies in different studies. In 2010, rivaroxaban is reported as a safe single oral anticoagulant [39,45], whereas a different result is reported in 2011 and 2012 where dabigatran is more cost-effective to be used with the positive benefit to harm ratio value [30-32]. Another study done in 2015 reported the same result as in 2011 and 2012 where the QALYs gained is higher with lower lifetime cost [7]. Apixaban is the most cost-effective drug reported in 2014 and 2016 [21,46-48]. This phenomenon also occurs in the US where the drug reported to be the most cost-effective varies throughout the years [8,9,13,23,27,29$30,49]$. But still a study done in 2016 concluded that all NOACs were more cost-effective than adjusted dosed warfarin with the value of QALY among all NOACs were close to each other [14]. In Asia region, a study done in Singapore concluded that rivaroxaban is more costeffective alternative to warfarin for the prevention of stroke [18]; in the Japan they believed that apixaban is more cost-effective in stroke prophylaxis and Hong Kong favoured dabigatran for stroke prophylaxis compared to the current treatment.

In the treatment of atrial fibrillation and stroke prevention, most of the studies found that apixaban is the most cost-effective alternative to other NOACs and warfarin [10-12,15,21-22,24,46$47,49]$. In the treatment of venous thromboembolism, apixaban also provides a superior alternative compared to other NOACs while warfarin and offers health benefits for a lower cost [25-26]. A study found that dabigatran is cost-effective compared to vitamin $\mathrm{K}$ antagonist in the treatment of venous thromboembolism [34]. Dabigatran and rivaroxaban are found to be more cost effective than warfarin in the treatment of pulmonary embolism [19]. A study found that both apixaban and warfarin are efficient therapy for pulmonary embolism [48].

Most of the studies reviewed show concern on the cost of drug and QALY. The economic burden in chronic conditions are not studied. Majority of cardiovascular diseases are chronic diseases such as stroke, therefore the substantial economic burden such as productivity as well as caregiver burden can be a significant concern. The lack of study in this aspect may be due to the fact that NOACs are relatively new drug and they have not been widely used worldwide. Since NOACs are quite novel, many of the economic evaluations are based on clinical trial data which may not reflect 
the real-world setting. The subjects in clinical trial may receive better care while in real-world clinical setting, many other factors such as local healthcare cost, health behavior, and drug adherence may vary. In addition to that, most of the economic evaluations had a short time horizon, so the direct application of the data to the real-world setting is impractical. In term of cost, the drug cost and other medical cost vary over time and this factor is not taken into account. Whilst in term of efficacy, the long-term effect of the drug may not be noted for a short period of follow-up, let the effect be beneficial or not.
Comparing the results from cost-effectiveness analysis across different health care settings poses a big challenge as the design of economic models for analysis varies from each other. It is not appropriate to compare studies in different settings because of the differences in treatment guidelines, real-world clinical practice, country's economy, and cost estimates used to populate models. Markov model is the most used however modifications of this model are made in many studies, which causes the results may not be coherent with each other. The difference of ICER threshold also should be noted, as a different threshold value may totally alter the cost-effectiveness of a drug Table 1.

Table 1

\begin{tabular}{|c|c|c|c|c|c|}
\hline Author & Study Design & Sample size & Inclusion /Exclusion & Outcome of interest & Conclusions \\
\hline $\begin{array}{c}\text { Krejczy M, et al. } \\
{[16]}\end{array}$ & $\begin{array}{l}\text { Markov decision } \\
\text { model, Monte } \\
\text { Carlo simulation }\end{array}$ & $\begin{array}{l}\text { Hypothetical } \\
\text { cohort RE- } \\
\text { LY (18113 } \\
\text { patients) }\end{array}$ & $\begin{array}{l}\text { Inclusion: Patients with non-valvular } \\
\text { atrial fibrillation using oral anticoag- } \\
\text { ulants dabigatran, rivaroxaban and } \\
\text { apixaban }\end{array}$ & $\begin{array}{l}\text { Quality-adjusted life } \\
\text { years (QALY), total costs, } \\
\text { and incremental cost-ef- } \\
\text { fectiveness ratios (ICER). }\end{array}$ & $\begin{array}{l}\text { At current market costs of the NOACs, } \\
\text { nontherapeutic regimens seem to be } \\
\text { cost-effective from a German public } \\
\text { health care insurance perspective. }\end{array}$ \\
\hline $\begin{array}{l}\text { Zheng Y, et al. } \\
\text { [7] }\end{array}$ & $\begin{array}{l}\text { Markov model } \\
\text { with 3-month } \\
\text { model cycles }\end{array}$ & 5990 & $\begin{array}{l}\text { Inclusion: Patients taking NOACs and } \\
\text { warfarin and having diseases: acute } \\
\text { thromboembolic and bleeding events, } \\
\text { as well as long-term consequences of } \\
\text { stroke, intracranial hemorrhage, and } \\
\text { acute myocardial infarction }\end{array}$ & Cost-effectiveness & $\begin{array}{l}\text { Dabigatran yields more total QALYs at } \\
\text { lower lifetime costs than apixaban and } \\
\text { rivaroxaban, dominating the other } 2 \\
\text { NOACs. }\end{array}$ \\
\hline $\begin{array}{c}\text { Kamae I, et al. } \\
{[24]}\end{array}$ & $\begin{array}{l}\text { Lifetime Markov } \\
\text { model }\end{array}$ & 1000 & $\begin{array}{l}\text { Inclusion: Patients with non-valvular } \\
\text { atrial fibrillation using oral anticoag- } \\
\text { ulants dabigatran, rivaroxaban and } \\
\text { apixaban }\end{array}$ & $\begin{array}{l}\text { Direct medical cost, } \\
\text { long-term care cost, and } \\
\text { quality-adjusted life } \\
\text { years (QALYs) }\end{array}$ & $\begin{array}{l}\text { Apixaban is a cost-effective alternative } \\
\text { to warfarin in Japan for stroke preven- } \\
\text { tion among patients with NVAF. }\end{array}$ \\
\hline $\begin{array}{l}\text { Lip GY, et al. } \\
\text { [46] }\end{array}$ & Markov model & $\begin{array}{l}\text { rivaroxaban, } \\
\mathrm{n}=7131, \\
\text { warfarin, } \mathrm{n}= \\
\quad 7133\end{array}$ & Inclusion: AF patients & $\begin{array}{l}\text { Life-years, quality-ad- } \\
\text { justed life years gained, } \\
\text { direct health care costs, } \\
\text { and incremental cost-ef- } \\
\text { fectiveness ratios. }\end{array}$ & $\begin{array}{c}\text { Apixaban may be a cost-effective } \\
\text { alternative to dabigatran } 150 \text { mg BID, } \\
\text { dabigatran } 110 \text { mg BID, and rivaroxaban } \\
20 \mathrm{mg} \text { once daily for stroke prevention } \\
\text { in AF patients. }\end{array}$ \\
\hline $\begin{array}{c}\text { Lanitis T, et al. } \\
\text { [48] }\end{array}$ & $\begin{array}{l}\text { Markov cohort } \\
\text { model }\end{array}$ & 1000 & $\begin{array}{l}\text { Inclusion: patients with atrial fibril- } \\
\text { lation taking apixaban, warfarin and } \\
\text { aspirin }\end{array}$ & $\begin{array}{l}\text { Health care costs and } \\
\text { life-years and quality-ad- } \\
\text { justed life years }\end{array}$ & $\begin{array}{l}\text { Apixaban was found to be a cost-effec- } \\
\text { tive alternative to warfarin and aspirin } \\
\text { for stroke prevention in patients with } \\
\text { AF in Sweden. }\end{array}$ \\
\hline $\begin{array}{c}\text { Verhoef, et al. } \\
\text { [12] }\end{array}$ & $\begin{array}{l}\text { Randomised } \\
\text { control trial and } \\
\text { cohort study }\end{array}$ & 100 & $\begin{array}{l}\text { Inclusion: healthy with atrial fibril- } \\
\text { lation (AF), ischaemic stroke (IS), } \\
\text { transient ischaemic attack (TIA), myo- } \\
\text { cardial infarction (MI), SE, intracranial } \\
\text { haemorrhage (ICH), extracranial hae- } \\
\text { morrhage (ECH), disability and death. } \\
\quad \text { Age-specified (70 years old) }\end{array}$ & $\begin{array}{l}\text { 1) Quality-adjusted life- } \\
\text { year (QALY) values } \\
\text { 2) Incremental cost-effec- } \\
\text { tiveness ratios (ICERs) }\end{array}$ & $\begin{array}{l}\text { Apixaban,Rivaroxaban and dabiga- } \\
\text { tran are cost-effective alternatives to } \\
\text { coumarin derivatives in the UK, while } \\
\text { in the Netherlands, only apixaban and } \\
\text { dabigatran could be considered cost } \\
\text { effective. }\end{array}$ \\
\hline $\begin{array}{l}\text { Ye Wang, et al. } \\
\text { [18] }\end{array}$ & Markov model & $\begin{array}{l}\text { Hypothetical } \\
\text { cohort }\end{array}$ & $\begin{array}{l}\text { Inclusion: Anticoagulation, Atrial } \\
\text { fibrillation, Cost-effectiveness, Dabiga- } \\
\text { tran, Rivaroxaban, Warfarin }\end{array}$ & $\begin{array}{l}\text { Direct medical costs, } \\
\text { Quality-adjusted life } \\
\text { years (QALYs) }\end{array}$ & $\begin{array}{l}\text { Rivaroxaban may be a cost-effective } \\
\text { alternative to warfarin for the preven- } \\
\text { tion of stroke in patients with AF in } \\
\text { Singapore. }\end{array}$ \\
\hline $\begin{array}{l}\text { Andrej Janzic, } \\
\text { et al. [17] }\end{array}$ & Cohort study & $\begin{array}{l}18112 \text { pa- } \\
\text { tients }\end{array}$ & $\begin{array}{l}\text { Inclusion: Nondisabled, } 70 \text {-year- } \\
\text { old patients with increased risk for } \\
\text { stroke who started anticoagulation } \\
\text { treatment. Four additional health } \\
\text { states were defined: nondisabled } \\
\text { and on treatment; disabled and on } \\
\text { treatment; disabled and off treatment; } \\
\text { and nondisabled and off treatment. } \\
\text { Patients at any health state were at } \\
\text { risk for ischaemic stroke, systemic } \\
\text { embolism, myocardial infarction, } \\
\text { intracranial haemorrhage and other } \\
\text { major haemorrhage. }\end{array}$ & $\begin{array}{l}\text { 1) Quality-adjusted } \\
\text { life-years (QALYs) } \\
\\
\text { 2) Incremental } \\
\text { cost-effectiveness ratio } \\
\text { (ICER) for each NOAC, } \\
\text { compared with warfarin } \\
\text { treatment. }\end{array}$ & $\begin{array}{l}\text { NOACs were cost-effective alternatives } \\
\text { to warfarin at TTR up to } 65 \% \text { however } \\
\text { at better warfarin control, the ICERs } \\
\text { of NOACs were higher, indicating that } \\
\text { warfarin was the preferred treatment. }\end{array}$ \\
\hline
\end{tabular}




\begin{tabular}{|c|c|c|c|c|c|}
\hline $\begin{array}{l}\text { Alexander } \\
\text { Mensch, et al. } \\
{[38]}\end{array}$ & $\begin{array}{l}\text { Randomised } \\
\text { control trial and } \\
\text { cohort study }\end{array}$ & Unclear & $\begin{array}{l}\text { Inclusion: Patients aged } 65 \text { years with } \\
\text { non-valvular AF and without contrain- } \\
\text { dications to anticoagulation who were } \\
\text { at moderate to high risk of stroke. }\end{array}$ & $\begin{array}{l}\text { Quality adjusted life } \\
\text { years (QALYs) }\end{array}$ & $\begin{array}{l}\text { Treatment with rivaroxaban was found } \\
\text { to be more effective than warfarin treat- } \\
\text { ment, with an ICER of } € 15,207 \text { per QALY } \\
\text { gained favoring rivaroxaban. }\end{array}$ \\
\hline $\begin{array}{l}\text { Gregory YHLip, } \\
\text { et al. [47] }\end{array}$ & Cohort study & $\begin{array}{l}1000 \text { pa- } \\
\text { tients }(100 \\
\text { patients per } \\
\text { year) }\end{array}$ & $\begin{array}{l}\text { Inclusion: Cohort of patients with } \\
\text { the condition over a lifetime horizon. } \\
\text { NVAF without complications, NVAF } \\
\text { with stroke or NVAF with bleeding }\end{array}$ & $\begin{array}{l}\text { Mean life-years (LYs) } \\
\text { Quality-adjusted life- } \\
\text { years (QALYs) } \\
\text { Costs per patient. } \\
\text { Incremental cost effec- } \\
\text { tiveness ratio (ICER) of } \\
\text { a currency (euro, USD, } \\
\text { or any other currency) } \\
\text { per quality adjusted } \\
\text { life years (QALY). }\end{array}$ & $\begin{array}{l}\text { The comprehensive assessment of the } \\
\text { long-term efficacy, safety, and tolera- } \\
\text { bility profile of apixaban in this study, } \\
\text { generated through means of an econom- } \\
\text { ic model, predicted that the drug would } \\
\text { provide an attractive alternative to oth- } \\
\text { er NOACs in the prevention of thrombo } \\
\text { embolic events in patients with AF. }\end{array}$ \\
\hline $\begin{array}{l}\text { Martin Krejczy, } \\
\text { et al. [42] }\end{array}$ & $\begin{array}{l}\text { Randomised } \\
\text { control trial and } \\
\text { cohort study }\end{array}$ & $\begin{array}{c}\text { Hypothet- } \\
\text { ical cohort } \\
\text { ENGAGE-AF } \\
(21,105 \\
\text { patients) RE- } \\
\text { LY }(18,113 \\
\text { patients), } \\
\text { ROCKET } \\
\text { (14,264 pa- } \\
\text { tients), ARIS- } \\
\text { TOTLE trials } \\
\text { (18,201 } \\
\text { patients) }\end{array}$ & $\begin{array}{l}\text { Inclusion: Healthy with NVAF, } \\
\text { transient ischemic attack, ischemic } \\
\text { stroke (fatal, moderate to severe, and } \\
\text { mild), haemorrhage (fatal, moderate } \\
\text { to severe intracranial, mild intracra- } \\
\text { nial, major noncerebral, and minor } \\
\text { noncerebral), myocardial infarction } \\
\text { (MI), recurrent and combined events, } \\
\text { and cardiovascular mortality using } \\
\text { the results from the ENGAGE-AF trial } \\
\text { and costs. }\end{array}$ & & $\begin{array}{l}\text { Edoxaban in addition to apixaban may } \\
\text { be regarded as the most cost-effective } \\
\text { NOAC from a German public health care } \\
\text { insurance perspective. }\end{array}$ \\
\hline $\begin{array}{l}\text { Zanfina Ademi, } \\
\text { et al. [11] }\end{array}$ & Cohort study & 1000 & $\begin{array}{l}\text { Inclusion: } \mathrm{AF} \text { or flutter and at least } \\
\text { one of the following risk factors: age } \\
\text { of at least } 75 \text { years; previous stroke, } \\
\text { transient ischaemic attack (TIA) or } \\
\text { systemic embolism; symptomatic } \\
\text { heart failure within the previous three } \\
\text { months or left ventricular ejection } \\
\text { fraction (LVEF) of no more than } 40 \% \text {; } \\
\text { diabetes mellitus; and hypertension } \\
\text { requiring pharmacologic treatment. }\end{array}$ & $\begin{array}{l}\text { Life per gained (LYG) and } \\
\text { quality adjusted life years } \\
\text { (QALYS) }\end{array}$ & $\begin{array}{l}\text { Compared to warfarin, apixaban is likely } \\
\text { to represent a cost-effective means of } \\
\text { preventing stroke-related morbidity and } \\
\text { mortality in patients with AF. }\end{array}$ \\
\hline Soyon et al. [9] & Markov model & $\begin{array}{l}\text { Hypothetical } \\
\text { cohort }\end{array}$ & $\begin{array}{l}\text { Inclusion: Cost effectiveness, apix- } \\
\text { aban, stroke, atrial fibrillation }\end{array}$ & $\begin{array}{l}\text { Costs in } 2012 \text { US\$, qual- } \\
\text { ity-adjusted life-years } \\
\text { (QALYs), life years saved, } \\
\text { incremental cost-effec- } \\
\text { tiveness ratios }\end{array}$ & $\begin{array}{l}\text { In patients with } \mathrm{AF} \text { and at least one ad- } \\
\text { ditional risk factor for stroke,treatment } \\
\text { with apixaban may be a cost-effective } \\
\text { alternative to warfarin. }\end{array}$ \\
\hline $\begin{array}{l}\text { Martin Krejczy, } \\
\text { et al. [42] }\end{array}$ & Markov model & 1000 & $\begin{array}{l}\text { Inclusion: Stroke, apixaban, cost-effec- } \\
\text { tiveness, atrial fibrillation, new oral } \\
\text { anticoagulant. }\end{array}$ & $\begin{array}{l}\text { LYs, QALYs, and costs } \\
\text { accumulated }\end{array}$ & $\begin{array}{l}\text { Apixaban may be a cost-effective } \\
\text { alternative to dabigatran } 150 \text { mg BID, } \\
\text { dabigatran } 110 \mathrm{mg} \text { BID, and rivaroxaban } \\
20 \mathrm{mg} \text { once daily for stroke prevention } \\
\text { in AF patients from the perspective of } \\
\text { the United Kingdom National Health } \\
\text { Services }\end{array}$ \\
\hline $\begin{array}{l}\text { Tereza Lanitis, } \\
\text { et al. [20] }\end{array}$ & Markov model & 1000 & $\begin{array}{l}\text { Inclusion: Cost effectiveness, apix- } \\
\text { aban, anticoagulants, venous throm- } \\
\text { boembolism, }\end{array}$ & $\begin{array}{l}\text { Number of events } \\
\text { avoided in } 1000 \text { cohort } \\
\text { patients, Total costs, Life } \\
\text { years, QALYs (Quality } \\
\text { Adjusted Life Years), Cost } \\
\text { per QALY gained over a } \\
\text { patient's lifetime }\end{array}$ & $\begin{array}{l}\text { Apixaban would provide a superior } \\
\text { alternative to other NOACs in terms of } \\
\text { the initial treatment of VTE and preven- } \\
\text { tion of recurrences as well as reduction } \\
\text { in bleeding events over } 6 \text { months of } \\
\text { treatment, offering favourable health } \\
\text { benefits for a lower cost. }\end{array}$ \\
\hline $\begin{array}{l}\text { Paul Dorian, et } \\
\text { al. [21] }\end{array}$ & $\begin{array}{l}\text { Markov cohort } \\
\text { model }\end{array}$ & 1000 & $\begin{array}{l}\text { Inclusion: Aspirin, Stroke prevention, } \\
\text { Apixaban, Cost-effectiveness, Atrial } \\
\text { fibrillation }\end{array}$ & $\begin{array}{l}\text { Life expectancy, Qual- } \\
\text { ity-adjusted life years } \\
\text { (QALYs) }\end{array}$ & $\begin{array}{l}\text { Based on randomized trial data, apix- } \\
\text { aban is a cost-effective alternative to } \\
\text { warfarin and aspirin, in VKA suitable } \\
\text { and VKA unsuitable patients with AF, } \\
\text { respectively. }\end{array}$ \\
\hline $\begin{array}{l}\text { Amanda R } \\
\text { Harrington, et } \\
\text { al. [13] }\end{array}$ & $\begin{array}{l}\text { Markov deci- } \\
\text { sion-analysis } \\
\quad \text { model }\end{array}$ & $\begin{array}{l}\text { Hypothetical } \\
\text { cohort }\end{array}$ & $\begin{array}{l}\text { Inclusion: Anticoagulation, atrial } \\
\text { fibrillation, cost-effectiveness }\end{array}$ & $\begin{array}{l}\text { Costs, QALYs, and ICERs, } \\
\text { Willingness to Pay }\end{array}$ & $\begin{array}{l}\text { In patients with nonvalvular atrial fibril- } \\
\text { lation and an increased risk of stroke } \\
\text { prophylaxis, apixaban } 5 \mathrm{mg} \text {, dabigatran } \\
150 \mathrm{mg} \text {, and rivaroxaban } 20 \mathrm{mg} \text { were all } \\
\text { cost-effective alternatives to warfarin. }\end{array}$ \\
\hline
\end{tabular}




\begin{tabular}{|c|c|c|c|c|c|}
\hline $\begin{array}{l}\text { Merlijn W J van } \\
\text { Leent, et al. } \\
\text { [33] }\end{array}$ & $\begin{array}{l}\text { A retrospective } \\
\text { observational } \\
\text { study }\end{array}$ & $\begin{array}{l}\text { dabigatran } \\
\text { (2553) } \\
\text { warfarin } \\
(2554)\end{array}$ & $\begin{array}{c}\text { Inclusion: Cost effectiveness, Dabig- } \\
\text { atran }\end{array}$ & QALYs, ICER & $\begin{array}{l}\text { Inserting these real-world data into a } \\
\text { cost-effectiveness analysis for pa- } \\
\text { tients diagnosed with DVT, dabigatran } \\
\text { appeared to be a cost-saving alternative } \\
\text { to VKAs in the Netherlands in the base } \\
\text { case. }\end{array}$ \\
\hline $\begin{array}{l}\text { Thomas David- } \\
\text { son, et al. [35] }\end{array}$ & $\begin{array}{l}\text { A decision ana- } \\
\text { lytic simulation } \\
\text { model following } \\
\text { a Markov design }\end{array}$ & $\begin{array}{l}\text { Hypothetical } \\
\text { cohort RE-LY } \\
\text { (18 113 } \\
\text { patients) }\end{array}$ & $\begin{array}{l}\text { Cost effectiveness, atrial fibrillation } \\
\text { and anticoagulants. }\end{array}$ & $\begin{array}{l}\text { number of strokes pre- } \\
\text { vented, life years gained, } \\
\text { quality-adjusted life } \\
\text { years (QALYs) gained }\end{array}$ & $\begin{array}{l}\text { Dabigatran is a cost-effective treatment } \\
\text { in Sweden, as its incremental cost-ef- } \\
\text { fectiveness ratio is below the normally } \\
\text { accepted willingness to pay limit. }\end{array}$ \\
\hline $\begin{array}{l}\text { James V Free- } \\
\text { man, et al. [27] }\end{array}$ & $\begin{array}{l}\text { Markov decision } \\
\text { model. }\end{array}$ & $\begin{array}{l}\text { Hypothetical } \\
\text { cohort RE-LY } \\
\text { (18 113 } \\
\text { patients) }\end{array}$ & $\begin{array}{l}\text { Cost effectiveness, Warfarin, Dabiga- } \\
\text { tran, Atrial Fibirlation, Stroke }\end{array}$ & $\begin{array}{l}\text { Quality-adjusted life- } \\
\text { years (QALYs), Costs (in } \\
2008 \text { U.S. dollars), Incre- } \\
\text { mental cost-effectiveness } \\
\text { ratios }\end{array}$ & $\begin{array}{l}\text { In patients aged } 65 \text { years or older with } \\
\text { nonvalvular AF at increased risk for } \\
\text { stroke (CHADS } 2 \text { score } 1 \text { or equivalent), } \\
\text { dabigatran may be a cost-effective alter- } \\
\text { native to warfarin depending on pricing } \\
\text { in the United States. }\end{array}$ \\
\hline $\begin{array}{l}\text { Hooman Ka- } \\
\text { mel, et al. [28] }\end{array}$ & $\begin{array}{l}\text { Randomized con- } \\
\text { trolled trial and } \\
\text { Cohort study }\end{array}$ & $\begin{array}{l}\text { Hypothetical } \\
\text { cohort }\end{array}$ & $\begin{array}{l}\text { Inclusion:Patients with nonvalvular } \\
\text { atrial fibrillation, prior stroke or tran- } \\
\text { sient ischemic attack, and no contrain- } \\
\text { dication to anticoagulation. Exclusion: } \\
\text { Patients with disability, ischemic } \\
\text { stroke, intracerebral hemorrhage, } \\
\text { recurrent orcombined stroke and/or } \\
\text { intracerebral hemorrhage, and death }\end{array}$ & QALY, ICER & $\begin{array}{l}\text { Dabigatran is likely to be a cost-effec- } \\
\text { tive alternative to warfarin for stroke } \\
\text { prevention in typical patients with atrial } \\
\text { fibrillation who have had a stroke or } \\
\text { transient ischemia attack. }\end{array}$ \\
\hline $\begin{array}{l}\text { Andy M Chang, } \\
\text { et al, [36] }\end{array}$ & Markov Model & 244 & $\begin{array}{l}\text { Inclusion: Patients with non-valvular } \\
\text { atrial fibrillation taking dabigratan } \\
\text { and warfarin }\end{array}$ & $\begin{array}{l}\text { Incremental cost-effec- } \\
\text { tiveness ratio (ICER). }\end{array}$ & $\begin{array}{l}\text { Dabigratan is favored for stroke prophy- } \\
\text { laxis in patients with non-valvular atrial } \\
\text { fibrillation in Hong Kong under the } \\
\text { current hospital's perspective and pro- } \\
\text { vided a reference for further compar- } \\
\text { isons under patient and subsidization } \\
\text { perspectives. }\end{array}$ \\
\hline $\begin{array}{l}\text { Anuraag R Kan- } \\
\text { sal, et al. [30] }\end{array}$ & Markov Model & $\begin{array}{l}\text { Hypothetical } \\
\text { cohort RE-LY } \\
\text { (18 113 } \\
\text { patients) }\end{array}$ & $\begin{array}{l}\text { Inclusion:Patients with atrial fibrilla- } \\
\text { tion taking dabigatran etexilate and } \\
\text { warfarin and aspirin }\end{array}$ & $\begin{array}{l}\text { Quality-adjusted life } \\
\text { years (QALY), Incremen- } \\
\text { tal cost-effectiveness } \\
\text { ratio(ICER) }\end{array}$ & $\begin{array}{l}\text { Patients with atrial fibrillation will be } \\
\text { having more cost-effective with the use } \\
\text { of dabigratan etexilate as a first-line } \\
\text { treatment for prevention of stroke and } \\
\text { systemic embolism. }\end{array}$ \\
\hline $\begin{array}{l}\text { Shimoli V Shah, } \\
\text { et al. [29] }\end{array}$ & Markov model & $\begin{array}{l}\text { Hypothetical } \\
\text { cohort RE-LY } \\
(18113 \\
\text { patients) }\end{array}$ & $\begin{array}{l}\text { Inclusion: Patients with atrial fibrilla- } \\
\text { tion taking dabigratan and warfarin }\end{array}$ & $\begin{array}{l}\text { Quality-adjusted life } \\
\text { years (QALY) }\end{array}$ & $\begin{array}{l}\text { Dabigratan is more cost-effective in atri- } \\
\text { al fibrillation populations at high risk } \\
\text { of hemorrhage or high risk of stroke } \\
\text { whereas warfarin is more cost-effective } \\
\text { in moderate-risk of atrial fibrillation } \\
\text { populations. }\end{array}$ \\
\hline $\begin{array}{l}\text { Joyce HS You, et } \\
\text { al. [37] }\end{array}$ & Markov model & 18000 & $\begin{array}{l}\text { Inclusion: Patients with atrial fibrilla- } \\
\text { tion taking dabigratan }\end{array}$ & $\begin{array}{l}\text { Qality-adjusted life-year } \\
\text { (QALY) and Incremen- } \\
\text { tal cost-effectiveness } \\
\text { ratio(ICER) }\end{array}$ & $\begin{array}{l}\text { Genotype-guided anticoagulation } \\
\text { service to be accepted as cost-effective } \\
\text { would increase if the quality of life on } \\
\text { warfarin and dabigratan therapy are } \\
\text { compatible and genotype-guided ser- } \\
\text { vice achieves high TTR. }\end{array}$ \\
\hline $\begin{array}{l}\text { Doug Coyle, et } \\
\text { al. [15] }\end{array}$ & $\begin{array}{l}\text { Markov cohort } \\
\text { model }\end{array}$ & $\begin{array}{c}\text { Hypothetical } \\
\text { cohort RE-LY } \\
(18,113 \\
\text { patients) } \\
\text { ROCKET } \\
\text { (14,264 pa- } \\
\text { tients) ARIS- } \\
\text { TOTLE trials } \\
(18,201 \\
\text { patients) }\end{array}$ & $\begin{array}{l}\text { Inclusion: Patients with non-valvular } \\
\text { atrial fibrillation taking dabigratan,ri- } \\
\text { varoxaban,apixaban and warfarin }\end{array}$ & $\begin{array}{l}\text { Quality-adjusted life-year } \\
\text { (QALY), Cost, Incremen- } \\
\text { tal cost per QALY gained(- } \\
\text { ICUR) }\end{array}$ & $\begin{array}{l}\text { Rivaroxaban and dabigratan }(110 \mathrm{mg}) \\
\text { are unlikely to be cost-effective whereas } \\
\text { apixaban and dabigratan }(150 \mathrm{mg}) \text { are } \\
\text { optimal. }\end{array}$ \\
\hline $\begin{array}{l}\text { Anuj Shah, et } \\
\text { al. [14] }\end{array}$ & Cohort Studies & 10000 & $\begin{array}{l}\text { Inclusion:Patients with ICH, myocar- } \\
\text { dial infarction (MI), stroke, and ECH. } \\
\text { Exclusion: Unclear }\end{array}$ & $\begin{array}{l}\text { QALY, Cost effective, } \\
\text { Incremental cost-effec- } \\
\text { tiveness ratio(ICER) }\end{array}$ & $\begin{array}{c}\text { All the NOACs we compared were more } \\
\text { effective than adjusted dosed warfarin; } \\
\text { however, the QALY among all NOACs } \\
\text { was similar. }\end{array}$ \\
\hline
\end{tabular}




\begin{tabular}{|c|c|c|c|c|c|}
\hline $\begin{array}{l}\text { William J } \\
\text { Canestaro, et } \\
\text { al. [22] }\end{array}$ & $\begin{array}{l}\text { Randomized con- } \\
\text { trolled trial and } \\
\text { Cohort study }\end{array}$ & $\begin{array}{c}\text { Hypothetical } \\
\text { cohortRE-LY } \\
(18,113 \\
\text { patients) } \\
\text { ROCKET } \\
(14,264 \text { pa- } \\
\text { tients)ARIS- } \\
\text { TOTLE trials } \\
(18,201 \\
\text { patients) }\end{array}$ & $\begin{array}{l}\text { Inclusion: Patients that are newly } \\
\text { diagnosed atrial fibrillation who were } \\
\text { eligible for treatment with warfarin. } \\
\text { Exclusion: Unclear }\end{array}$ & $\begin{array}{l}\text { Incremental cost-effec- } \\
\text { tiveness ratios }\end{array}$ & $\begin{array}{l}\text { Although all the novel oral anticoagu- } \\
\text { lants produce greater quality-adjusted } \\
\text { life expectancy than warfarin, they may } \\
\text { not represent good value for money. }\end{array}$ \\
\hline $\begin{array}{l}\text { Torbjørn Wis- } \\
\text { løf, et al. [44] }\end{array}$ & $\begin{array}{l}\text { randomized clini- } \\
\text { cal trials (RCT) }\end{array}$ & Unclear & Unclear & ICER & $\begin{array}{l}\text { Apixaban and dabigatran ( } 150 \mathrm{mg} \text { up } \\
\text { to age } 80 \text { years, } 110 \text { mg after age } 80 \\
\text { years) seem to be the most effective and } \\
\text { cost-effective alternatives. }\end{array}$ \\
\hline $\begin{array}{l}\text { Carla Rognoni, } \\
\text { et al. [43] }\end{array}$ & $\begin{array}{l}\text { randomized clini- } \\
\text { cal trials (RCT) }\end{array}$ & Unclear & Unclear & $\begin{array}{l}\text { QALY Incremental } \\
\text { cost-utility ratio (ICUR) }\end{array}$ & $\begin{array}{l}\text { Edoxaban resulted cost-effective versus } \\
\text { warfarin in } 92.3 \% \text { of the simulations } \\
\text { using a willingness-to-pay threshold of } \\
€ 25,000 \text { per QALY and in } 96 \% \text { of the } \\
\text { simulations using a willingness-to-pay } \\
\text { threshold of } € 50,000 \text { per QALY }\end{array}$ \\
\hline $\begin{array}{l}\text { Andreas Cle- } \\
\text { mens, Siyang } \\
\text { Peng, Sarah } \\
\text { Brand, } 2014\end{array}$ & Cohort & $\begin{array}{c}\text { Hypothetical } \\
\text { cohortRE-LY } \\
(18113 \\
\text { patients })\end{array}$ & Unclear & $\begin{array}{l}\text { Clinical event costs avoid- } \\
\text { ed cost-effectiveness }\end{array}$ & $\begin{array}{c}\text { Dabigatran was cost-effective versus } \\
\text { warfarin in US patients with atrial fibril- } \\
\text { lation regardless of age of treatment } \\
\text { initiation }\end{array}$ \\
\hline $\begin{array}{l}\text { Alpesh Amin, et } \\
\text { al. [23] }\end{array}$ & $\begin{array}{l}\text { randomized clini- } \\
\text { cal trials (RCT) }\end{array}$ & $\begin{array}{l}\text { RE-SONATE } \\
\text { (4199 pa- } \\
\text { tients) EIN- } \\
\text { STEIN-EXT } \\
\text { (3449 pa- } \\
\text { tients) AM- } \\
\text { PLIFY-EXT } \\
\text { (2486 } \\
\text { patients) }\end{array}$ & Unclear & Medical cost avoidance & $\begin{array}{l}\text { Apixaban is associated with the greatest } \\
\text { medical cost avoidance, which is driven } \\
\text { mainly by a greater reduced rate in } \\
\text { recurrent VTE than other NOACs versus } \\
\text { placebo and also a reduction in MB rate. }\end{array}$ \\
\hline $\begin{array}{l}\text { Alpesh Amin, et } \\
\text { al. [23] }\end{array}$ & $\begin{array}{l}\text { randomized clini- } \\
\text { cal trials (RCT) }\end{array}$ & 23,525 & Unclear & Total medical cost & $\begin{array}{c}\text { Apixaban and dabigatran are more } \\
\text { cost-effective compared with warfarin } \\
\text { while warfarin is more cost-effective } \\
\text { than rivaroxaban. }\end{array}$ \\
\hline $\begin{array}{l}\text { Bauersachs R, } \\
\text { et al. [45] }\end{array}$ & $\begin{array}{l}\text { randomized clini- } \\
\text { cal trials (RCT) }\end{array}$ & 4646 & $\begin{array}{l}\text { Inclusion: Acute, symptomatic, } \\
\text { objectively confirmed proximal DVT, } \\
\text { without symptomatic pulmonary } \\
\text { embolism. Exclusion: received thera- } \\
\text { peutic doses of low-molecular-weight } \\
\text { heparin, fondaparinux, or unfraction- } \\
\text { ated heparin for more than } 48 \text { hours } \\
\text { or if they had received more than a } \\
\text { single dose of a vitamin K antagonist } \\
\text { before randomization }\end{array}$ & Rate of recurrence & Oral rivaroxaban provide an effective, \\
\hline $\begin{array}{c}\text { Büller HR, et al. } \\
\text { [39] }\end{array}$ & $\begin{array}{l}\text { randomized clini- } \\
\text { cal trials (RCT) }\end{array}$ & 4832 & $\begin{array}{l}\text { Exclusion: indication for a vitamin } \\
\text { K antagonist; a creatinine clearance } \\
\text { below } 30 \text { ml per minute; clinically } \\
\text { significant liver disease or an alanine } \\
\text { aminotransferase level that was more } \\
\text { than three times the upper limit of the } \\
\text { normal range; bacterial endocarditis; } \\
\text { active bleeding or a high risk of bleed- } \\
\text { ing contraindicating anticoagulant } \\
\text { treatment; a systolic blood pressure } \\
\text { of more than } 180 \text { mm Hg or a diastolic } \\
\text { blood pressure of more than } 110 \mathrm{~mm} \\
\mathrm{Hg} \text {. }\end{array}$ & $\begin{array}{l}\text { A fixed-dose regimen of } \\
\text { rivaroxaban alone was } \\
\text { non inferior to standard } \\
\text { therapy for the initial } \\
\text { and long-term treatment } \\
\text { of pulmonary embolism } \\
\text { and had a potentially } \\
\text { improved benefit-risk } \\
\text { profile }\end{array}$ & $\begin{array}{l}\text { The use of rivaroxaban as a single oral } \\
\text { agent for patients with venous throm- } \\
\text { boembolism is effective }\end{array}$ \\
\hline $\begin{array}{c}\text { Lanitis T, et al. } \\
{[48]}\end{array}$ & Cohort study & $\begin{array}{l}\text { Hypothetical } \\
\text { cohort } 1000 \\
\text { patients }\end{array}$ & Unclear & $\begin{array}{l}\text { An economic evalua- } \\
\text { tion of the currently } \\
\text { prescribed treatments } \\
\text { for stroke prevention in } \\
\text { patients with NVAF in- } \\
\text { cluding warfarin, aspirin } \\
\text { and NOAC from French } \\
\text { payer perspective }\end{array}$ & $\begin{array}{l}\text { The efficiency frontier approach demon- } \\
\text { strated that warfarin and apixaban } \\
\text { are efficient therapies in terms of cost, } \\
\text { QALYs, and subsequent efficiency for } \\
\text { patients with AF in France. }\end{array}$ \\
\hline
\end{tabular}




\begin{tabular}{|c|c|c|c|c|c|}
\hline $\begin{array}{l}\text { Vivek Y Reddy, } \\
\text { et al. [19] }\end{array}$ & Markov model & $\begin{array}{c}\text { Ruff et } \\
\text { al., } 2014 \\
\text { (71 } 683 \\
\text { patients) } \\
\text { Holmes et al., } \\
2009 \text { (707 } \\
\text { patients), } \\
\text { [38] Hart et } \\
\text { al., 2007 (28 } \\
044 \text { patients) } \\
\text { Pisters et al., } \\
2010 \text { (3978 } \\
\text { patients) } \\
\text { Connelly } \\
\text { et al., 2009 } \\
\text { (18,113 } \\
\text { patients) }\end{array}$ & $\begin{array}{l}\text { Inclusion: Acute, symptomatic, } \\
\text { objectively confirmed proximal DVT, } \\
\text { without symptomatic pulmonary } \\
\text { embolism. Exclusion: received thera- } \\
\text { peutic doses of low-molecular-weight } \\
\text { heparin, fondaparinux, or unfraction- } \\
\text { ated heparin for more than } 48 \text { hours } \\
\text { or if they h Data related to aspirin and } \\
\text { clopidogrel }\end{array}$ & $\begin{array}{l}\text { The cost-effectiveness } \\
\text { and QALY of warfarin, } \\
\text { NOACs, and LAAC for } \\
\text { stroke risk reduction in } \\
\text { patients with nonvalvu- } \\
\text { lar AF. }\end{array}$ & $\begin{array}{l}\text { Both novel therapies demon-strated } \\
\text { cost-effectiveness relative to warfarin, } \\
\text { but only LAAC demonstrated cost sav- } \\
\text { ings by year } 10 \text { relative to warfarin and } \\
\text { by year } 5 \text { relative to NOACs. }\end{array}$ \\
\hline $\begin{array}{l}\text { Herbert JA, et } \\
\text { al. [40] }\end{array}$ & Markov model & 1000 & $\begin{array}{l}\text { Inclusion: Acute, symptomatic, } \\
\text { objectively confirmed proximal DVT, } \\
\text { without symptomatic pulmonary } \\
\text { embolism. Exclusion: received thera- } \\
\text { peutic doses of low-molecular-weight } \\
\text { heparin, fondaparinux, or unfraction- } \\
\text { ated heparin for more than } 48 \text { hours } \\
\text { or if they h }\end{array}$ & $\begin{array}{l}\text { Associated quality adjust- } \\
\text { ed life years, and health } \\
\text { care costs of Rivaroxaban } \\
\text { and VKAs }\end{array}$ & $\begin{array}{l}\text { Although RVX seems promising, there } \\
\text { is still uncertainty on whether RVX or } \\
\text { VKAs should be prescribed in premeno- } \\
\text { pausal women, mainly because of the } \\
\text { uncertainty on the risk of AUBs and } \\
\text { ischemic strokes. }\end{array}$ \\
\hline $\begin{array}{l}\text { Soyon Lee, et } \\
\text { al. [8] }\end{array}$ & Markov modeling & $\begin{array}{l}\text { Hypothetical } \\
\text { cohort } 1000 \\
\text { patients }\end{array}$ & $\begin{array}{l}\text { Inclusion:Patients of atrial fibrillation } \\
\text { taking rivaroxaban and warfarin. }\end{array}$ & $\begin{array}{l}\text { 1)Costs in } 2011 \text { United } \\
\text { States dollars }\end{array}$ & $\begin{array}{l}\text { Rivaroxaban may be cost-effective } \\
\text { alternative to warfarin in patients with } \\
\text { atrial fibrillation regardless of baseline } \\
\text { ischemic stroke risk. }\end{array}$ \\
\hline $\begin{array}{l}\text { Morais J, et al. } \\
{[41]}\end{array}$ & Markov modeling & $\begin{array}{c}\text { Hypothet- } \\
\text { ical cohort } \\
\text { ROCKET AF } \\
\text { clinical trials } \\
(14,000 \\
\text { patients })\end{array}$ & $\begin{array}{l}\text { Inclusion: Acute, symptomatic, } \\
\text { objectively confirmed proximal DVT, } \\
\text { without symptomatic pulmonary } \\
\text { embolism. Exclusion: received thera- } \\
\text { peutic doses of low-molecular-weight } \\
\text { heparin, fondaparinux, or unfraction- } \\
\text { ated heparin for more than } 48 \text { hours } \\
\text { or if they h }\end{array}$ & $\begin{array}{l}\text { 1)Incremental Life Years } \\
\text { (LYs) } \\
\text { 2) Quality-Adjusted Life } \\
\text { Years(QALYs) } \\
\text { 3)Incremental cost-effec- } \\
\text { tiveness ratios(ICERs) } \\
\text { 4)Incremental costs }\end{array}$ & $\begin{array}{l}\text { Rivaroxaban is cost-effective compared } \\
\text { with vitamin K antagonist therapy in a } \\
\text { trial-based setting, and also compared } \\
\text { to real-world antithrombotic prescrib- } \\
\text { ing in Portugal for stroke prophylaxis in } \\
\text { patients with atrial fibrillation. }\end{array}$ \\
\hline $\begin{array}{l}\text { Anuraag R Kan- } \\
\text { sal, et al. [30] }\end{array}$ & Markov modeling & $\begin{array}{l}\text { Hypothetical } \\
\text { cohort RE-LY } \\
\text { (18 } 113 \\
\text { patients) }\end{array}$ & $\begin{array}{l}\text { Inclusion:Patientswith atrial fibrilla- } \\
\text { tion takingDabigatran etexilate,warfa- } \\
\text { rin, aspirinandno therapy }\end{array}$ & $\begin{array}{l}\text { 1)Quality-adjusted life } \\
\text { years(QALYs) } \\
\text { 2)Incremental cost per } \\
\text { QALY }\end{array}$ & $\begin{array}{l}\text { Dabigatran offers a positive benefit } \\
\text { to harm ratio when compared with } \\
\text { warfarin. }\end{array}$ \\
\hline $\begin{array}{l}\text { J Stevanoic, et } \\
\text { al. [34] }\end{array}$ & Markov modeling & $\begin{array}{l}10,000 \text { adult } \\
\text { patients RE- } \\
\text { LY (18 113 } \\
\text { patients) }\end{array}$ & $\begin{array}{l}\text { Inclusion: Patients with venous } \\
\text { thromboembolism taking dabigratan }\end{array}$ & $\begin{array}{l}\text { 1)Quality-adjusted life } \\
\text { years (QALYs) } \\
\text { 2)Incremental cost-effec- } \\
\text { tiveness ratio(ICER) }\end{array}$ & $\begin{array}{l}\text { Dabigatran is likely to be a cost-effec- } \\
\text { tive or even cost-saving strategy for } \\
\text { treatment and secondary prevention of } \\
\text { venous thromboembolism compared to } \\
\text { vitamin K antagonists in the Nether- } \\
\text { lands. }\end{array}$ \\
\hline $\begin{array}{l}\text { Joshua Pink, et } \\
\text { al. [32] }\end{array}$ & Markov modeling & 50,000 & $\begin{array}{l}\text { Inclusion: Patients with non- valvular } \\
\text { atrial fibrillation taking dabigratane- } \\
\text { texilate and warfarin }\end{array}$ & $\begin{array}{l}\text { 1) Quality-adjusted life } \\
\text { years (QALYs) } \\
\text { 2) Incremental cost per } \\
\text { QALY }\end{array}$ & $\begin{array}{l}\text { Dabigatran offers a positive benefit } \\
\text { to harm ratio when compared with } \\
\text { warfarin. }\end{array}$ \\
\hline
\end{tabular}

There were several limitations in this systematic review. The differences in healthcare system across countries and the study designs making it not possible to compare results of economic models that are adopted from different perspectives. Additionally, differences in patients' health states, adherence to medication and healthcare resource use where the economic models did not take account of. This variability did not reflect real-world clinical practices. The economic models used are adopted across various time horizons, with many of the models estimating cost over 3 months to 1 year. A careful consideration should be paid to the selection of appropriate time horizons for future models.

\section{Conclusions}

Numerous studies investigated novel oral anticoagulants (NOACs), namely, apixaban, edoxaban, rivaroxaban and dabigatran, since they were introduced to clinical practice, especially for their various roles in management of cardiovascular diseases. With proven NOAC clinical superiority and the lower need of follow-up visits and lab tests, NOAC economic profile is a broad area of research. The current study managed to review 43 studies investigating NOACs based on the inclusion criteria. The review investigated studies that emphasized on QALYs, total costs and incremental cost-effectiveness ratios (ICER) and willingness to pay. Despite 
the variations in quality, sampling, design of studies investigating NOACs, all studies reported that NOAC are more cost-effective than warfarin in terms of indirect costs and quality-adjusted life year (QALYs). Generally, among NOAC, dabigatran is more costeffective than apixaban, rivaroxaban and edoxaban as it yields more total QALYs at lower lifetime costs. Nonetheless, apixaban is the most cost-effective among all NOACs in the treatment of atrial fibrillation, stroke prevention, and venous thromboembolism. However, the comparison between NOACs in the treatment of pulmonary embolism was less conclusive, which is an open are of research for future studies evaluating economic profile of NOAC with pulmonary embolism. Besides that, further research is also needed to assess the impact of the reduction in economic burden for a more holistic pharmacoeconomic evaluation of NOAC.

\section{Acknowledgment}

The author would like to acknowledge Universiti Sains Malaysia, School of Pharmaceutical Sciences for providing the facilities and resources to ease the access of databases.

\section{Conflict of Interest}

No conflict of interest.

\section{References}

1. Oktay E (2015) Will Noacs Become the New Standard of Care in Anticoagulation Therapy? International Journal of The Cardiovascular Academy 1(1): 1-4

2. Fang MC, Chang Y, Hylek EM, Rosand J, Greenberg SM, et al. (2004) Advanced Age, Anticoagulation Intensity, And Risk for Intracrania Hemorrhage Among Patients Taking Warfarin for Atrial Fibrillation. Annals of Internal Medicine 141(10): 745-752.

3. Hylek EM, Go AS, Chang Y, Jensvold NG, Henault LE, et al. (2003) Effect of Intensity of Oral Anticoagulation on Stroke Severity and Mortality in Atrial Fibrillation. New England Journal of Medicine 349(11): 10191026

4. Connolly SJ, Ezekowitz MD, Yusuf S, Eikelboom J, Oldgren J, et al. (2009) Dabigatran Versus Warfarin in Patients with Atrial Fibrillation. New England Journal of Medicine 361(12): 1139-1151.

5. Ghanny S, Crowther M (2013) Treatment with Novel Oral Anticoagulants: Indications, Efficacy and Risks. Current Opinion in Hematology 20(5): 430-436.

6. Patel MR, Mahaffey KW, Garg J, Pan G, Singer DE, et al. (2011) Rivaroxaban Versus Warfarin in Nonvalvular Atrial Fibrillation. N Engl J Med 365: 883-891.

7. Zheng Y, Sorensen SV, Gonschior AK, Noack H, Heinrich Nols J, et al. (2014) Comparison of The Cost-Effectiveness of New Oral Anticoagulants for The Prevention of Stroke and Systemic Embolism In Atrial Fibrillation In A Uk Setting. Clin Ther 36(12): 2015-2028.

8. Lee, S, Anglade MW, Pisacane R, Kluger J (2012b) Cost-Effectiveness of Rivaroxaban Compared to Warfarin for Stroke Prevention in Atrial Fibrillation. Am J Cardiol 110(6): 845-851.

9. Lee S, Anglade MW, Pisacane R, Kluger J, Coleman CI (2012a) CostEffectiveness of Rivaroxaban Compared To Warfarin For Stroke Prevention In Atrial Fibrillation. Am J Cardiol 110(6): 845-851.

10. Lee S, Mullin R, Blazawski J, Coleman C I (2012c) Cost-Effectiveness of Apixaban Compared with Warfarin For Stroke Prevention In Atrial Fibrillation. Plos One 7: E47473.
11. Ademi Z, Pasupath, K, Liew D (2015) Cost-Effectiveness of Apixaban Compared to Warfarin in The Management of Atrial Fibrillation in Australia. Eur J Prev Cardiol 22: 344-353.

12. Verhoef TI, Redekop WK, Hasrat F, De Boer A, Maitland-Van Der Zee AH (2014) Cost Effectiveness of New Oral Anticoagulants for Stroke Prevention in Patients with Atrial Fibrillation in Two Different European Healthcare Settings. Am J Cardiovasc Drugs 14(16): 451-462.

13. Harrington AR, Armstrong EP, Nolan PE, Malone DC (2013) CostEffectiveness of Apixaban, Dabigatran, Rivaroxaban, and Warfarin for Stroke Prevention in Atrial Fibrillation. Stroke 44(6): 1676-1681.

14. Shah A, Shewale A, Hayes CJ, Martin BC (2016) Cost-Effectiveness of Oral Anticoagulants for Ischemic Stroke Prophylaxis Among Nonvalvular Atrial Fibrillation Patients. Stroke 47: 1555-1561.

15. Coyle D, Coyle K, Cameron C, Lee K, Kelly S, et al. (2013) CostEffectiveness of New Oral Anticoagulants Compared with Warfarin in Preventing Stroke and Other Cardiovascular Events in Patients with Atrial Fibrillation. Value Health 16(4): 498-506.

16. Krejczy M, Harenberg J, Marx S, Obermann K, Frolich L, et al. (2014) Comparison of Cost-Effectiveness of Anticoagulation with Dabigatran, Rivaroxaban and Apixaban In Patients with Non-Valvular Atrial Fibrillation Across Countries. J Thromb Thrombolysis 37(4): 507-523.

17. Janzic A, Kos M (2015) Cost Effectiveness of Novel Oral Anticoagulants for Stroke Prevention in Atrial Fibrillation Depending on The Quality of Warfarin Anticoagulation Control. Pharmacoeconomics 33(4): 395-408.

18. Wang Y, Xie F, Kong MC, Lee L H, Ng HJ, Ko Y (2014) Cost-Effectiveness of Dabigatran and Rivaroxaban Compared with Warfarin for Stroke Prevention in Patients with Atrial Fibrillation. Cardiovasc Drugs Ther 28(6): 575-585.

19. Reddy VY, Akehurst RL, Armstrong SO, Amorosi SL, Beard SM, et al. (2015) Time to Cost-Effectiveness Following Stroke Reduction Strategies in Af: Warfarin Versus Noacs Versus Laa Closure. J Am Coll Cardiol 66: 2728-2739.

20. Lanitis T, Leipold R, Hamilton M, Rublee D, Quon P, et al. (2016) CostEffectiveness of Apixaban Versus Other Oral Anticoagulants for The Initial Treatment of Venous Thromboembolism and Prevention of Recurrence. Clin Ther 38(3): 478-493.

21. Dorian P, Kongnakorn T, Phatak H, Rublee DA, Kuznik A, et al. (2014) Cost-Effectiveness of Apixaban Vs. Current Standard of Care for Stroke Prevention in Patients with Atrial Fibrillation. Eur Heart J 35(28): 18971906.

22. William J, Canestaro ARP, Jerry Avorn, Kouta Ito, Olga S Matlin, Troyen A, et al. (2013) Cost-Effectiveness of Oral Anticoagulants for Treatment of Atrial Fibrillation. Original Article 6: 724-731.

23. Amin A, Stokes M, Makenbaeva D, Wiederkehr D, Wu N. et al (2014) Estimated Medical Cost Reductions Associated with Use of Novel Oral Anticoagulants Vs Warfarin in a Real-World Non-Valvular Atrial Fibrillation Patient Population. J Med Econ 17: 771-781.

24. Kamae I, Hashimoto Y, Koretsune Y, Tanahashi N, Murata T, et al. (2015) Cost-Effectiveness Analysis of Apixaban Against Warfarin for Stroke Prevention in Patients with Nonvalvular Atrial Fibrillation in Japan. Clin Ther 37(12): 2837-2851.

25. Lanitis T, Kongnakorn T, Jacobson L, De Geer A (2014b) CostEffectiveness of Apixaban Versus Warfarin and Aspirin in Sweden For Stroke Prevention in Patients with Atrial Fibrillation. Thromb Res 134(2): 278-287.

26. Amin A, Jing Y, Trocio J, Lin J, Lingohr Smith M. et al (2015) Evaluation of Medical Costs Avoided when New Oral Anticoagulants are Used for Extended Treatment of Venous Thromboembolism Based on Clinical Trial Results. J Thromb Thrombolysis 40: 131-138.

27. Freeman JV, Zhu RP, Owens DK, Garber AM, Hutton DW, et al. (2011) Cost-Effectiveness of Dabigatran Compared with Warfarin for Stroke Prevention in Atrial Fibrillation. Ann Intern Med 154(1): 1-11. 
28. Kamel H, Johnston SC, Easton JD, Kim A S (2012) Cost-Effectiveness of Dabigatran Compared with Warfarin for Stroke Prevention in Patients with Atrial Fibrillation and Prior Stroke or Transient Ischemic Attack. Stroke 43: 881-883.

29. Shah SV, Gage BF (2011) Cost-Effectiveness of Dabigatran for Stroke Prophylaxis in Atrial Fibrillation. Circulation 123: 2562-2570.

30. Anuraag R, Kansal SVS, Ray Gani, Paul Robinson, Feng Pan, et al (2011) Cost-Effectiveness of Dabigatran Etexilate for the Prevention of Stroke and Systemic Embolism in Uk Patients with Atrial Fibrillation. Heart 98(7): 573-578.

31. Kansal AR, Sorensen SV, Gani R, Robinson P, Pan F, et al. (2012) CostEffectiveness of Dabigatran Etexilate For the Prevention of Stroke and Systemic Embolism in Uk Patients with Atrial Fibrillation. Heart 98(7): 573-588.

32. Pink J, Lane S, Pirmohamed M, Hughes DA (2011) Dabigatran Etexilate Versus Warfarin in Management of Non-Valvular Atrial Fibrillation in Uk Context: Quantitative Benefit-Harm and Economic Analyses. Bmj 343: D6333.

33. Van Leent MW, Stevanovic J, Jansman FG, Beinema M J, Brouwers JR, et al. (2015) Cost-Effectiveness of Dabigatran Compared to Vitamin-K Antagonists for The Treatment of Deep Venous Thrombosis in The Netherlands Using Real-World Data. PLoS One 10(8): E0135054.

34. Stevanovic J, De Jong LA, Kappelhoff BS, Dvortsin EP, Voorhaar M, et al. (2016) Dabigatran for The Treatment and Secondary Prevention of Venous Thromboembolism; A Cost-Effectiveness Analysis for The Netherlands. Plos One 11(10): E0163550.

35. Davidson T, Husberg M, Janzon M, Oldgren J, Levin LA (2013) CostEffectiveness of Dabigatran Compared with Warfarin for Patients with Atrial Fibrillation in Sweden. Eur Heart J 34(3): 177-183.

36. Chang AM, Ho JC, Yan BP, Yu CM, Lam YY, et al. (2013) Cost-Effectiveness of Dabigatran Compared with Warfarin for Stroke Prevention in Patients with Atrial Fibrillation--A Real Patient Data Analysis in A Hong Kong Teaching Hospital. Clin Cardiol 36(5): 280-285.

37. You JH, Tsui KK, Wong RS, Cheng G (2012) Cost-Effectiveness of Dabigatran Versus Genotype-Guided Management of Warfarin Therapy for Stroke Prevention In Patients With Atrial Fibrillation. Plos One 7(6): E39640.

38. Mensch A, Stock S, Stollenwerk B, Muller D (2015) Cost Effectiveness of Rivaroxaban for Stroke Prevention in German Patients with Atrial Fibrillation. Pharmacoeconomics 33(3): 271-283.
39. Buller HR, Prins MH, Lensin AW, Decousus H, Jacobson BF, et al. (2012) Oral Rivaroxaban for The Treatment of Symptomatic Pulmonary Embolism. N Engl J Med 366: 1287-1297.

40. Herbert JA, Rolden AHEMM, Gert Jan Van Der Wilt, Janneke PC, Grutters (2017) Uncertainty on The Effectiveness and Safety of Rivaroxaban in Premenopausal Women with Atrial Fibrillation: Empirical Evidence Needed. Bmc Cardiovascular Disorders 17.

41. Morais J, Aguiar C, Mcleod E, Chatzitheofilou I, Fonseca Santos I, et al. (2014) Cost-Effectiveness of Rivaroxaban for Stroke Prevention in Atrial Fibrillation in The Portuguese Setting. Rev Port Cardiol 33(9): 535-544.

42. Martin Krejczy JH, Martin Wehling, Konrad Obermann, Gregory Y H Lip (2015) Cost-Effectiveness of Anticoagulation in Patients with Nonvalvular Atrial Fibrillation with Edoxaban Compared to Warfarin in Germany. Biomed Research International 2015: 12.

43. Rognoni C, Marchetti M, Quaglini S, Liberato N L (2015) Edoxaban Versus Warfarin for Stroke Prevention in Non-Valvular Atrial Fibrillation: A Cost-Effectiveness Analysis. J Thromb Thrombolysis 39: 149-154.

44. Wisloff T, Hagen G, Klemp M (2014) Economic Evaluation of Warfarin Dabigatran, Rivaroxaban, And Apixaban For Stroke Prevention in Atrial Fibrillation. Pharmacoeconomics 32(6): 601-612.

45. Bauersachs R, Berkowitz SD, Brenner B, Buller HR, Decousus H, eta l. (2010) Oral Rivaroxaban for Symptomatic Venous Thromboembolism. N Engl J Med 363(14): 2499-2510.

46. Lip GY, Kongnakorn T, Phatak H, Kuznik A (2014a) Cost-Effectiveness of Apixaban Versus Other New Oral Anticoagulants for Stroke Prevention in Atrial Fibrillation. Clin Ther 36(2): 192-210.E20.

47. Lip GY, Kongnakorn T, Phatak H, Kuznik A, Lanitis T, et al. (2014b) CostEffectiveness of Apixaban Versus Other New Oral Anticoagulants for Stroke Prevention in Atrial Fibrillation. Clin Ther 36(2): 192-210.E20.

48. Lanitis T, Cotte FE, Gaudin AF, Kachaner I, Kongnakorn T et al. (2014a) Stroke Prevention in Patients with Atrial Fibrillation in France: Comparative Cost-Effectiveness of New Oral Anticoagulants (Apixaban, Dabigatran, And Rivaroxaban), Warfarin, And Aspirin. J Med Econ 17(8): 587-98.

49. Lip GY, Phatak H, Kuznik A, Lanitis T, Iloeje U (2014c) Cost-Effectiveness of Apixaban Versus Other New Oral Anticoagulants for Stroke Prevention in Atrial Fibrillation. Clin Ther 36(2): 192-210. 